aangesproken ook voor die, welke de vrouw ten bchoeve der huishouding heeft aangegaan, terwijl ingeval er geen goederengemeenschap bestaat, de man tegenover derden voor laatstbedoelde verbintenissen aansprakelijk is blijkens de bepalingen van de art. 160-162, 200, 201 en 248 B. W., daar in zijn handen zich in het algemeen bevinden de middelen ter bestrijding van de kosten der huishouding.

De hoogste rechter in het land heeft derhalve thans bevestigd de reeds in 1913 (10 Maart, N. J. 1913 pag. 603, W. 9473) voorzoover mij bekend toen voor 't eerst, door' de Haagsche Rechtbank verdedigde stelling, dat voor huishoudelijke schulden èn de vrouw èn de man aansprakelijk zijn. Reeds dat vomis vatte de ar'gumentatie in enkele zinnen knap te zamen, toen het overwoog:

„dat ook buiten het geval van gemeenschap van gocderen tusschen de echtgenooten, in welk geval de man reeds naar art. $176 \mathrm{~B} . \mathrm{W}^{\top}{ }^{1}$ ) aansprakelijk is, de man, als het hoofd der echtvereeniging en als ingevolge art. 162 B. W. verplicht zijn vrouw al hetgeen noodig is volgens zijn staat en vermogen te verschaffen, aansprakelijk is voor de huishoudelijke schulden;

dat zulks ook blijkt nit de artt. 200 en 201 van gezegd Wethoek, die het beginsel huldigen dat in de eerste plaats de man de kosten der huishouding betaalt;

dat mitsdien zelfs bij uitsluiting of beperking der gemeenschap van goederen, gelijk onderwerpelijk, waar appellanten zijn gehuwd in gemeenschap van vruchten en inkomsten, naar de wet de vrouw, handelende krachtens art. 164, bindt zoowel zich zelve als den man, en zulks te meer aannemelijk is te achten, omdat die wetsbepaling stamt uit het Oud-Hollandsche recht en volgens dat recht zulks evenzeer het geval was als zịnde huishoudelijke schuld gemeenschapsschuld";

\section{* * *}

Wij kumnen derhalve de lịn volkomen doortrekken : vanaf de oude rechtsgeleerden tot de latere bepalingen heeft steeds als systeem gegolden dat èn man èn vrouw gebonden waren.

De jurisprudentie, welke dit prineipe nu erkent, staat derhalve historisch sterk en tevens op den bodem der realiteit.

\section{F. J. DF KANTER}

1) Art. $176 \mathrm{~B}$. W. zegt dat de gemeenschap van goederen ,omvat wat hare lasten betreft, alle de schulden, door ieder der echtgenooten, hetzij voor, hetzij staande huwelijk, gemaakt".

\section{LASTIGE GEVALLEN}

$D_{c}$ bedoeling van deze rubriek is gelegenheid te bieden lastige gev'allen, die zich in de praktijk den accountant in zijn beroep voordoen of kunnen voordoen, - lastig, omdat er een onoplosbare tegenstrijdigheid tusschen theorie en praktijk schiont te bestaan - hier ter sprake te brengen, resp. ter oplossing aan den lezer voor te leggen. De Redactio, doet een voortdurend beroep op allen, die op zulke, gevallen" stuiten, om ze te formuleeren en bij den Secretaris in te zenden.

\section{Antwoord op Lastig Geval IX}

\section{Verantwoordelijkheid voor afschrijving bij het ontbreken van een vergelijkingsbasis}

Wanneer een accountant ,het altijj dr'uk hoeft over zijn ver'antwoordelijkheid" blijkt daaruit m.i. nog niet dat „hij zichzelf respecteert"'. Fr blijkt m.i. alleen uit, dat die accountant ontrent zijn verantwoordelijkheid nog niet met zich zelf tot klaarheid is gekomen; dat hij op het gebied van zijn verantwoordelijk- heid onevenwichtig, althans nog nict ,in rust" is. Dat is voor' iemand, die uit hoofde van zijn beroep verantwoordelijkheid moet kummen dragen, juist niet geschikt om zịn zelfrespect to verhoogen, noch om anderen respect af te dwingen.

I $k$ ben altijd op mijn hoede voor den man, die mij telkenmale met nadruk verzekert, ,alleen eerlijk" te willen handelen. Hij acht dat blijkbaar niet ranzelfsprekend; hij heeft het noodig zichzelf - over het hoofd van den toehoorder heen -- dit beginsel voor te houden. Met een accountant die het altijd druk heeft over zijn verantwoordelijkheid zou ik on dezelfde reden voorzichtig willen zijn.

Het is mịj niet bekend dat er collega's zijn, die de verantwoordelijkheid voorstellen als een begrip waarover te avond of te morgen wel voor bijna $100 \%$ overeenstemming zal ziju bereikt. De heer Keuzenliamp zegt, dat er ,velen" van zijn collega's zoo over denken. Hoc is hen dat bekend? Waar hebben zij hun denkbeclden gepubliceerd? Collega. Keuzenlamp bemint het voorbchoud. Had hij bij deze zinsnede nict zelf een voorbehoud moeten maken?

Ongetwijfeld is verantwoordelịkheid een zuiver persoonlịjk begrip en ik deel nict alleen de mecning van den hoer Keuzenlamp dat nimmer cen paar honderd mensehen daarover grelijli zullen gaan denken, mall ik meen zelfs dat het tot de uitzonderingen zal behooren, wamneer twee menschen daarover gehee] gelịk oordeclen.

Ferschil in verantwoordelijkheidsbegrip behoeft evenwel nict tc weerhouden het bereiken ran overeenstemming omtrent vaktcehnische arngelegenheden. Ook met cen subjectief verantwoordelijkheidshegrip kumurn de accountants vaststellen, welke velantwoordelijkheid ten opzichte van de juistheid zij bij het onderteekenen van de jaarrekening in principe op zich nemen. Zij kunnen ontrent de prineipicele punten, waromtrent zij thans onderling van gevoelen verdecld zijn, zich een gedragslijn kic. zen, zoodat het publiek weet of b.v. de onderteekening van cen jarrekening door den accountant inhoudt de verzekering dat geen geheime reserves aanwezig zijn, de goederenvoorraad door den accountant zelf is opgenomen on hijj er dus voor instaat dat hịj in natura naar aard en kwaliteit aanwezig is, dat hij de notulen gelezen heeft en deze niets bevatten wat een ander licht op de gegevens van de jaarrekening zou doen vallen, dat hij alle cijfer-entrôles zelf heeft uitgevoerd en niet op eenige wijze heeft gestcund op de interne controle enz. enz.

Het komt mij roor dat het publick recht heeft on te weten of zulks al dan niet het geval is cn dat de accountants recht hebben om te weten of zulks bij hun contrôlearbeid al dan niet van hen wordt geeischt.

Het is bekend dat de accountants angstvallig weigeren zich ontrent de\%c eischen op deze punten definiticf uit te spreken en het streven om tot een definitieve uitspraak te komen kan niet worden w.cggevalagd met het te ridiculiseeren door het overdicven voor te stellen.

Het bepalen der afschrịving is in zekeren zin, het bepalen van het tockomstig nut - in geld uitgedrukt - dat men van het object verwacht. Wanneer - wat vrijwel regel is - de economische levensduur van het object korter is dan de technische levensduur, zal de schatting in hoofdzaak berusten op economische en bedrijfs-ceonomische overwegingen. Het beoordeelen van afschrijvingen behoort darom zeker tot de taak van den accoun. tant. In het bedrijfsleven zijn voor bepaalde activa ten opzichte van de afschrijvingen ,normen" ontstaan, b.v. meubilair $10 \%$. Zich daarbị aanpassende zal de accountant als regel die normen aanvaarden. Hieruit vloeit evenwel volstrekt niet voort, dat hij zich van een oordecl zou moeten - of zelfs zou kunnen onthouden. wanneer er geen norm is.

Is het inderdaad de bedocling van collega Keuzenkamp om to stellen dat de ,vergelijkingshasis" het roornaamste middel voor 
den accountant is on de juistheid van afschrijvingen te beoordeelen? Ik deel dan zịn meening niet; ik acht dit een middel van veel lager orde dan het zelfstandig oordcel van den accountant ontrent de waarde, wellse door het gebruik van het object in het productieproces is opgegaan, daarbij steunende op zijn cigen bedrijfs-cconomische inzichten.

Het ,gegeven" dat het geva] ,lastig" maakt, n.l. dat er geon soortgelijke bedrijven bestaan en er dus een vergelijkingshasis voor de afsehrijving ontbrcekt, is lawrom voor mij van bijkoms. tigen alard on maalit het geval weinig lastigen dan het uit zijn and is.

Blijkbaar moet in let bedoelde geval de accountant ten behoeve van den ,bouwhecr" bij den aamnemer de kosten van een regiewerk controlecren.

$\mathrm{F}_{\mathrm{r}}$ is dus een rekening en er komen daarop afschrijvingeu voor. 1)e accountant zal zich vergewissen op welke grondslagen men die afsehrijvingen hceft vast gresteld en die grondslagen beoordeclen en de daarop rustende berekening controlecren. Zijn oordecl zal hij ter kennis brengen van zijn opdrachtgever. Waarom hij hicr een ,voorbehoud" zou moeten maken is mij niet duidelijk.

IIet bedrag der afsehrijvingen js natuurlijk niet met juistheid vast te stellen. Het ooldeel van den accountant zal zich daarom moeten bepalen tot de redelijkheid der grondslagen en juistheid der berekeningen. Zijn conclusie zal zijn : ,aanncmelijk" of „onaannemelịjk". De omstandigheid dat de accountant bij deze onderzocken als regel niet met een korte verklaring behoeft to volstaan, maar cen rapport zal kumnen uitbrengen, maakt het hem mogelijk zijn opdrachtgever volledig op de hoogte te brengen met eventuecle bezwaren, welke hij tegen de toegepaste afschrijvingen heeft.

Wil men het uitzonderingsgeral stellen, dat de accountant met een korte verklaring zal moeten volstaan, dan is het voor mij aan geen twijfel onderherig, dat de accountant ,verplicht" is zich een zelfstandig oordeel - ook wanneer er geen vergelijkingsbasis is - omtrent de toegepaste afschrijvingen te vormen en in die verklaring van zijn bezwaren tegen die afsehrijvingen melding te maken. Wanncer hịj zou volstaan met een ,voorbehoud", zon hij s.m.m. zijn taak nict naas behooren hehben ver'richt.

Wat do heer Keuzentamp bedoelt met het, spelen met de wiskundige reserve"' is mij niet helder! Wij hebben in dit blad een polemick over het ,voorbchond" bij de wiskundige reserve gehad. De heeren de Blacy en Keuzenkamp waren de inzenders. die van meening waren cat een ,voorbehoud" noodig was wanneer de accountant de wiskundige leserve niet zelf had gecontrolecrd. De heer de Blacy heeft later medegedeeld tot ander inzicht te zijn gekomen. Wammeer ik de op dit gebied bij uitstek deskundige - Collega de Goey - groed heb begrepen, acht ook hij cen voorbehond allcen op grond dat de accountant zolf de wiskundige reserve niet heeft gecontroleerd, nict noodzakelijk. Plijft collega Kenzenhamp hịj zijn a anvankelijke mecning? Maar waarin zit nu het. ,spelen'"?

\section{R. A. DT.JKWR}

\section{BOEKBEOORDEELING}

\section{A. Verrijn stuart. - De Grondslagen der Volkshnis-} houding 3e druk.

Het verheugt mij, dat het werk van den Utrechtschen hooglecraar zoozer de belangstelling blijft louden, dat nu reeds een 3e druk noodig is geworden. Ik verheng mij daarover, omdat het bock naar mijn meening een zeer goede analyse geeft van de belangrijkste vraagstukken der theoretische economie overeenkomstig de zicnswijze van de Oostenrijksche school, duidelijker en voolal exacter van betoog dan het overgroote meerendeel van de buitenlandsche worken, die hier te lande veelal in de studicprogramma's worden genoemd. Met deze uitspraak oordeel ik niet over de beteekenis van die prohlemen roor de theorie, noch ores de boteekenis der opvattingen van de Oostenrijksche sehool voor het huidige stadium van ontwikkeling der economie; on niet te worden misverstan : ik sla die beteekenis heel wat lager aan dan de schrijver. Maar dit verhindert mij niet, het werk can te bevelen als cen uitmuntend studie-boek voor iederen Nederlander, die een inzicht wil krijgen in de theoretische economie, overeenkomstig de thans welhaast klassiek geworden opvattingen van de Oostenrijkers.

Is.

Prof. Dr. W. L. P. A. Molengraaff. Tnleiding tot het Nederlandsche Handelsrecht.

Men zendt ons ter aankondiging den zoo juist bij de Erven F. Bohn verschenen 3den druk van Prof. Molengraff's ,Inleiding".

Nadat het werkje voor het eerst in 1921 was versehenen to $i^{2}$ vervanging van T. M. C. Asser's „Schets" kwam in 1925 d. tweede druk uit. Sedert dien zijn in verband met nieuwe wettelijke bepalingen weer ecnige bclangrijke wijzigingen noodig ge worden, welke thans in dezen 3den druk aangebracht zijn.

Zoo is het nieuwe zeerecht, dat nog als supplement aan den 2 den druk was toegevoegd, thans in den 3 den druk verwerkt. De wet op de arbeidsovereenkomst van kapitein en schepelingen, waarvan de inwerking-treding binnenkort te verwachten is, is reeds in den tekst opgenomen; de thans vigeerende regeling is in een bijlage behandeld. De wet op de N.V. van 1928 en op de Coöperatieve Vereeniging van 1925 makkte een wijziging van hoofdstuk VII noodzakelijk. Ook de hoofdstukken betreffende het handelspapier en het faillissement en de surséance van betaling ondergingen wijziging.

Door een en ander is de omvang van het boek met ecn kleine 40 bladz. toegenomen.

Eenige aambereling heeft het bekende werkje wcl niet mecr noodig.

T. L.

Tien jaar organisatiewerk door Ir. Ernst Hymans, Ir. $I^{r}$. $\Pi^{r}$. van Gogh en $J$. Rentenaar. Uitgave van $J$. Munsses, Purmerend 1930.

Dit werk is een verzameling van opstellen, die vroeger ver'. schenen zijn in tijdschriften of in den vorm van pracadviezen en voordrachten. Met dezen herdruk viert het Raadgevend Bureau voor Organisatic onder leiding van de schrijvers zijn tienjarig hestaan. De schrijvers mogen net dit jubilenm zoowel als met deze jubileum-uitgaaf worden gelukgewenscht: zij hebben in die jaren veel nuttig werk op het gebied van de wetenschappelijke bedrijfs-organisatie verricht en het thans gepubliceerde boek geeft van dat werk een belangwekkend en leerzaam beeld.

Als herdruk van vroegere publicaties komt dit werk niet in aammerking voor cen gedetailleerde kritiek. T'rouwens, die zou ook nict gemakkelijk gegeven kunnen worden, daar het mecren deel der opstellen de beschrijving geeft van de oplossingen, dic de schrijvers in hun praktijk voor een reeks van problemen op het gelsied der organisatic hebben uitgedacht.

In verschillende opstellen wordt gesproken over het plannen en de contrôle op de productie; over functie-diagrammen en 